\title{
Effect of microbial inoculants on the quality and aerobic stability of bermudagrass round-bale haylage
}

\author{
K. G. Arriola, ${ }^{*}$ O. C. M. Queiroz, ${ }^{*}$ J. J. Romero, ${ }^{*}$ D. Casper,† E. Muniz, ${ }^{\star}$ J. Hamie, ${ }^{*}$ and A. T. Adesogan* ${ }^{* 1}$ \\ ${ }^{*}$ Department of Animal Sciences, Institute of Food and Agricultural Sciences, University of Florida, Gainesville 32606 \\ †Department of Animal Sciences, South Dakota State University, Brookings 57007
}

\section{ABSTRACT}

The objective of this study was to compare the efficacy of using 4 commercially available microbial inoculants to improve the fermentation and aerobic stability of bermudagrass haylage. We hypothesized that the microbial inoculants would increase the fermentation and aerobic stability of the haylages. Bermudagrass (4-wk regrowth) was harvested and treated with (1) deionized water (control); (2) Buchneri 500 (B500; Lallemand Animal Nutrition, Milwaukee, WI) containing $1 \times 10^{5}$ of Pediococcus pentosaceus and $4 \times 10^{5}$ of Lactobacillus buchneri 40788; (3) Biotal Plus II (BPII; Lallemand Animal Nutrition) containing $1.2 \times 10^{5}$ of P. pentosaceus and Propionibacteria freudenreichii; (4) Silage Inoculant II (SI; AgriKing Inc., Fulton, IL) containing $1 \times 10^{5}$ of Lactobacillus plantarum and P. pentosaceus; and (5) Silo King (SK; AgriKing Inc.), containing 1 $\times 10^{5}$ of L. plantarum, Enterococcus faecium, and $P$. pentosaceus, respectively. Forty round bales ( 8 per treatment; $441 \pm 26 \mathrm{~kg} ; 1.2 \times 1.2 \mathrm{~m}$ diameter) were made and each was wrapped with 7 layers of plastic. Twenty bales were stored for $112 \mathrm{~d}$ and the remaining 20 were stored for $30 \mathrm{~d}$ and sampled by coring after intermediary storage periods of $0,3,7$, and $30 \mathrm{~d}$. The $\mathrm{pH}$ of control and inoculated haylages sampled on $\mathrm{d} 3$ did not differ. However, B500 and BPII had lower pH $(5.77 \pm 0.04$ vs. $6.16 \pm 0.04 ; 5.06 \pm 0.13$ vs. $5.52 \pm$ 0.13 ) than other treatments by $\mathrm{d} 7$ and 30 , respectively. At final bale opening on d 112, all treatments had lower $\mathrm{pH}$ than the control haylage $(4.77 \pm 0.07$ vs. $5.37 \pm$ 0.07). The B500, BPII, and SI haylages had greater lactic acid and lactic-to-acetic acid ratios than SK and control haylages. No differences were detected in neutral detergent fiber digestibility, dry matter losses, dry matter, lactic and acetic acid concentrations, and yeast and coliform counts. The SK haylage had lower clostridia counts compared with the control (1.19 \pm 0.23 vs. $1.99 \pm 0.23 \mathrm{cfu} / \mathrm{g})$. Treatments B500, BPII, SI, and SK tended to reduce mold counts and they

Received May 27, 2014.

Accepted October 5, 2014.

${ }^{1}$ Corresponding author: adesogan@ufl.edu improved aerobic stability by $236,197,188$, and $95 \%$, respectively, compared with the control $(276 \pm 22$ vs. $99 \pm 22 \mathrm{~h}$ ).

Key words: Bermudagrass haylage, silage inoculant

\section{INTRODUCTION}

Ensiling is an alternative forage storage method to making hay that requires relatively less drying of the forage for successful preservation. Tifton 85 bermudagrass (Cynodon dactylon) is an improved tropical grass cultivar that is widely used in southern US dairy systems because it has greater NDF digestibility than other grasses adapted to the region (Hill et al., 1993). However, ensiling bermudagrass is challenging due to its low concentration of readily fermentable carbohydrates (Kunkle et al., 1988). Inoculants are applied to forage to improve their fermentation by rapidly reducing the $\mathrm{pH}$, thereby reducing losses of DM or to improve aerobic stability by inhibiting the growth of spoilage-causing yeasts. Due to their ability to ferment glucose to antifungal VFA, such as acetate and propionate (Moon, 1983), propionic acid bacteria have been applied to silage to improve aerobic stability (Dawson et al., 1998; Filya et al., 2004). However, such attempts have been unsuccessful in several studies (Higginbotham et al., 1998; Filya et al., 2006; Arriola et al., 2011 a,b) because the acidic conditions in the silo inhibited their growth and ability to compete with lactic acid bacteria (Weinberg et al., 1995). Forages ensiled with obligate heterofermentative Lactobacillus buchneri have typically improved the aerobic stability of forages (Adesogan et al., 2003; Kleinschmit et al., 2005; Huisden et al., 2009; Arriola et al., 2011b). However, application of L. buchneri alone can increase DM losses slightly (Ranjit and Kung, 2000). Therefore, L. buchneri is often combined with homofermentative or facultative heterofermentative bacteria in inoculants to constrain DM losses and improve aerobic stability (Driehuis et al., 2001; Adesogan et al., 2004; Arriola et al., 2011 a,b).

Only a few studies have examined effects of inoculant application to bermudagrass silage on the quality and aerobic stability of the silage. Adesogan et al. (2004) 
showed that microbial inoculants or molasses could improve the fermentation and quality of bermudagrass silage. Vendramini et al. (2012) reported that aerobic stability of bermudagrass silage was greater when it was treated with microbial inoculants instead of molasses or nothing. Both of these studies were conducted on bermudagrass that had been ensiled in mini-silos. No published studies were found that examined effects of inoculation of the bermudagrass round-bale haylage used in commercial practice on many dairies in the southern United States. The objective of our study was to compare the efficacy of using 4 commercially available microbial inoculants to improve the fermentation and aerobic stability of bermudagrass haylage. We hypothesized that the microbial inoculants would increase the fermentation and aerobic stability of the haylages.

\section{MATERIALS AND METHODS}

\section{Forages and Treatments}

An existing stand of Tifton 85 bermudagrass on a 23-ha field at the University of Florida Santa Fe Beef Unit (Alachua, FL) was fertilized with $526 \mathrm{~kg} / \mathrm{ha}$ of 17-0-10 (N-P-K) on May 3, 2010, and 3.4 tons/ha of lime on May 21, 2010. Approximately $280 \mathrm{~kg} / \mathrm{ha}$ of 34-0-0 (N-P-K) were applied after the first cutting of the 4 -wk regrowth on June 17, 2010. The second 4-wk regrowth was harvested at a stubble height of $8 \mathrm{~cm}$ with a 3-m wide mower (Disco 3000 TC model, Claas, Harsewinkel, Germany) fitted with a conditioner on July 7,2010 . The grass was wilted for $2.5 \mathrm{~h}$ and then treated with or without inoculants in the windrow before baling. Mowing started at $1000 \mathrm{~h}$ to avoid the morning dew and ended at about $1600 \mathrm{~h}$. Baling and wrapping started immediately after the 2.5 -h wilt such that the first and last bales were made at approximately 1300 and $1830 \mathrm{~h}$, respectively. A John Deere 468 (John Deere, Moline, IL) round baler and a McHale wrapper (991BC, McHale, Ballinrobe, County Mayo, Ireland) were used.

Inoculants were reconstituted in $12 \mathrm{~L}$ of deionized water and sprayed onto the forage in the windrow using the tractor-mounted, 57-L, continuous-flow sprayer (FIMCO, North Sioux City, SD) described by Krueger et al. (2008). The sprayer was fitted with a 3-nozzle boom and mounted on the tractor in front of the baler to ensure the forage was sprayed with the inoculant just before the grass entered the baler chamber. The sprayer was switched off and about half a windrow of untreated forage was run through the baler after each treatment to clean out the baler and avoid cross contamination. The field was divided into 5 blocks and each treatment was applied to windrows in each block to ensure that each treatment was applied to comparable forage. The following treatments were applied in the stated sequence: (1) water (control); (2) Buchneri 500 inoculant (B500; Lallemand Animal Nutrition, Milwaukee, WI), applied at $9.9 \mathrm{mg} / \mathrm{kg}$ of fresh forage to supply $1 \times 10^{5}$ $\mathrm{cfu} / \mathrm{g}$ of a mixture of Pediococcus pentosaceus and $4 \times$ $10^{5}$ L. buchneri 40788 as well as sufficient Trichoderma reesei $\beta$-glucanase, xylanase, and galactomannase to release 441, 1,258, and $20 \mathrm{mg}$ of glucose/min per gram, respectively; (3) Biotal Plus II inoculant (BPII; Lallemand Animal Nutrition), applied at $4.0 \mathrm{mg} / \mathrm{kg}$ of fresh forage to supply $1 \times 10^{5} \mathrm{cfu} / \mathrm{g}$ of a mixture of $P$. pentosaceus and Propionibacteria freudenreichii, as well as sufficient $\beta$-glucanase, xylanase, and galactomannanase to release 1,215 and 3,456 , and $54 \mathrm{mg}$ of glucose/min per gram, respectively; (4) Silage Inoculant II (SI; AgriKing Inc., Fulton, IL applied at $4.0 \mathrm{mg} / \mathrm{kg}$ of fresh forage to supply $1.2 \times 10^{5} \mathrm{cfu} / \mathrm{g}$ of a mixture of Lactobacillus plantarum and $P$. pentosaceus as well as sufficient $\beta$-glucanase (T. reesei), $\alpha$-amylase (Aspergillus oryzae), xylanase (T. reesei), and galactomannanase (T. Reesei) to release $1,260,630,684$, and $115 \mathrm{mg}$ of glucose/min per gram, respectively; and (5) Silo King inoculant (SK; AgriKing Inc.), applied at $7.9 \mathrm{mg} / \mathrm{kg}$ of fresh forage to supply $1 \times 10^{5}$ of a mixture of L. plantarum, Enterococcus faecium, and P. pentosaceus, as well as sufficient Aspergillus oryzae amylase, Bacillus subtilis amylase, and Trichoderma longibrachiatum cellulase for 5,000,000, 2,100,000, and 520,000 dinitrosalisylic acid units, respectively. The bacteria composition and enzyme activities of the inoculants were stipulated by the manufacturers. Their lactic acid bacteria populations were counted by pour plating on de Man, Rogosa, Sharpe agar (Oxoid, Basingstoke, UK) and incubating for $48 \mathrm{~h}$ at $32^{\circ} \mathrm{C}$ before they were applied.

Forty round bales ( 8 per treatment; $441 \pm 26 \mathrm{~kg} ; 1.2$ $\times 1.2 \mathrm{~m}$ diameter) were made and each was wrapped with 7 layers of white, 6 mil $(0.152 \mathrm{~mm})$ stretch plastic (Sunfilm silage wrap, AEP Industries Inc., Montvale, NJ) and stored. Twenty bales (4 per treatment) were opened after $112 \mathrm{~d}$ of storage. Bale weights were recorded immediately after they were wrapped on $\mathrm{d} 0$ and just before they were opened on d 112. These weights and the corresponding DM concentrations were used to calculate DM losses. The remaining 20 bales were stored for $30 \mathrm{~d}$ and 3 core samples were taken from different sites on each one with a silage corer (Star Quality Samplers, Edmonton, Canada) and frozen $\left(-4^{\circ} \mathrm{C}\right)$ after 0 (approximately $30 \mathrm{~min}$ after wrapping), 3, 7, and 30 $\mathrm{d}$ of storage. Silage tape was used to seal the coring site after each sampling. Four representative samples of the forage taken from several windrows at different times after mowing but before wilting on $\mathrm{d} 0$ were frozen $\left(-4^{\circ} \mathrm{C}\right)$ for subsequent analysis. 


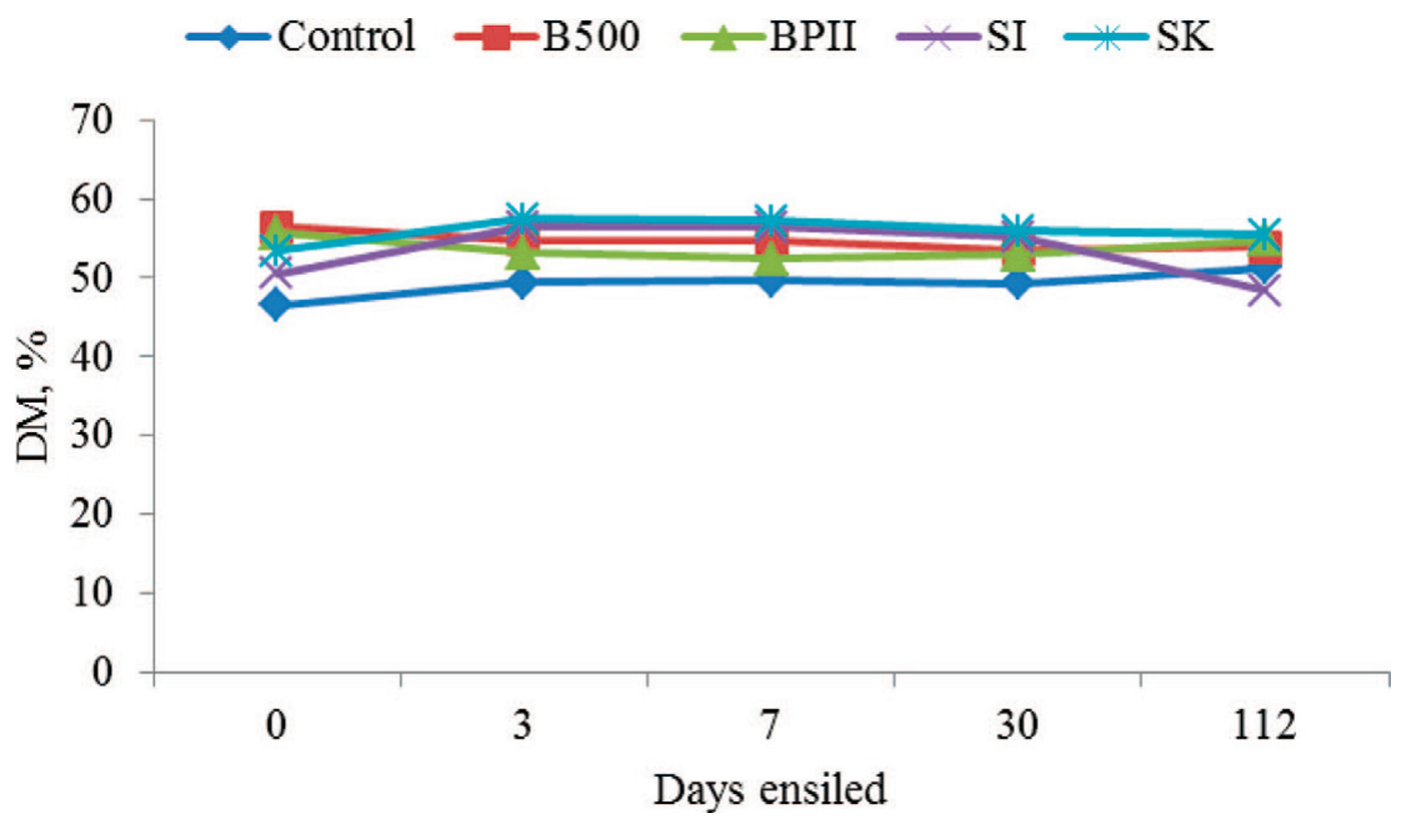

Figure 1. Effects of microbial inoculant treatment on the DM concentration (\%) of wilted bermudagrass haylage after different ensiling periods. Control $=$ no inoculant; $\mathrm{B} 500=$ Pediococcus pentosaceus and Lactobacillus buchneri; $\mathrm{BPII}=$ P. pentosaceus and Propionibacteria freudenreichii; $\mathrm{SI}=$ Lactobacillus plantarum and $P$. pentosaceus; $\mathrm{SK}=$ L. plantarum, Enterococcus faecium, and P. pentosaceus. Standard errors for the data for d $0,3,7,30$, and 112 were $3.6,2.1,2.0,1.9$, and 2.2, respectively. Means for treatment, time, and the interaction had $P$-values of 0.001 , 0.45, and 0.20, respectively. However, the control mean was less $(P<0.05)$ than those of B500 and BPII on d 0. Color version available online.

\section{Chemical Analysis}

Subsamples of the mown unwilted forage samples taken on $\mathrm{d} 0$ and the core samples taken after storage for $0,3,7$, and $30 \mathrm{~d}$ were analyzed for $\mathrm{pH}$ and $\mathrm{DM}$ concentration. Fifty grams of each sample were mixed with $450 \mathrm{~mL}$ of distilled water and blended using a Stomacher Lab-Blender 400 (Tekmar Company, Cincinnati, OH) for $1 \mathrm{~min}$ and the $\mathrm{pH}$ of the fluid was measured with an electrode (Accumet XL25 pH meter, Fisher Scientific, Pittsburgh, PA). Dry matter concentrations were measured in a forced-draft oven set at $60^{\circ} \mathrm{C}$ for $48 \mathrm{~h}$. Additional samples of the mown unwilted forage were sent to AnaLab (AgriKing Inc.) for analysis of $\mathrm{pH}$ and total lactic acid bacteria (as described previously), chemical composition (AOAC International, 1999; DM: method 935.29, ash: method 942.05, ADF: method 973.18, and CP: method 990.03), and buffering capacity (McDonald and Henderson, 1962). Amylase and sulfite were used in the NDF analysis (AOAC International, 1999; method 2002.04) and the results were expressed inclusive of residual ash. Samples from bales ensiled for 112 d of storage were also submitted to AnaLab for analysis of chemical composition, yeasts, clostridia, and molds (AOAC International, 1999; method 997.02), $\mathrm{NH}_{3} \mathrm{~N}$ (Peters et al., 2003), soluble protein (Krishnamoorthy et al., 1982), acid-detergent insoluble protein, and neutral detergent insoluble protein (AOAC International,
1999; methods 973.18 and 2002.04; respectively), as well as lactic acid and VFA (Cancalon, 1993). In vitro 48-h DM digestibility was determined after incubating forage in buffered rumen fluid using Daisy Incubators (Ankom Technology, Macedon, NY). The rumen fluid was collected from the AnaLab artificial rumen that was fed a diet of $1.35 \%$ ground shelled corn, $4.79 \%$ SBM, $1.49 \%$ vitamin mineral supplement, $17.5 \%$ alfalfa haylage, and $75 \%$ corn silage and was validated against cow rumen fluid by Ayangbile et al. (1995). In vitro 30-h NDF digestibility was estimated using NDF concentrations measured with an Ankom Fiber Analyzer on in vitro 48-h DM digestibility samples and residues

Table 1. Composition of mowed unwilted Tifton 85 bermudagrass forage

\begin{tabular}{lc}
\hline Measure & Value \\
\hline DM, \% & $33.9 \pm 1.9$ \\
Total lactic acid bacteria, cfu/g & $1.17 \times 10^{4}$ \\
pH & $6.65 \pm 0.04$ \\
Buffering capacity & $231 \pm 5.2$ \\
Ash, \% of DM & $5.89 \pm 0.5$ \\
CP, \% of DM & $20.4 \pm 0.2$ \\
ADF, \% of DM & $31.2 \pm 1.2$ \\
NDF, \% of DM & $62.8 \pm 2.4$ \\
Hemicellulose, \% of DM & $31.6 \pm 1.2$
\end{tabular}

${ }^{1}$ Buffering capacity $(\mathrm{pH} 4>6)=$ equivalent of $1 N$ sodium hydroxide per kilogram of forage DM. 
using the method described previously. Temperature sensors (Onset Computer Corporation, Bourne, MA) were placed at the center of bags containing $1 \mathrm{~kg}$ of haylage within $20-\mathrm{L}$ plastic buckets and set to record the temperature every $30 \mathrm{~min}$ for $14 \mathrm{~d}$. Aerobic stability was denoted by the time (h) that elapsed before haylage temperature increased by at least $2^{\circ} \mathrm{C}$ above the room temperature of $23^{\circ} \mathrm{C}$.

\section{Statistical Analysis}

The experiment had a completely randomized design and data were analyzed with the Mixed procedure of SAS (v. 9.2, SAS Institute Inc., Cary, NC). The statistical model used to analyze the data, except $\mathrm{pH}$ and $\mathrm{DM}$ concentration, included the fixed effect of treatment and the random effect of bale. The $\mathrm{DM}$ and $\mathrm{pH}$ data were analyzed with a similar model that also included time and interaction with time and repeated measures and slice statements. Due to differences in harvest times for different bales on the day of ensiling (d 0), DM concentrations at harvest were used as a covariate in the statistical models for analyzing the rest of the results. The PDIFF statement of SAS, which is based on Fisher's F-protected least significant different test, was used to compare least square means. Significance was declared at $P \leq 0.05$ and tendencies at $0.05<P$ $<0.10$.

\section{RESULTS AND DISCUSSION}

The chemical composition of the harvested forage (Table 1) was typical of those produced previously in Florida (Adesogan et al., 2004; Dean et al., 2005; Vendramini et al., 2010) and Georgia (West et al., 1998). The CP concentration was relatively high because the grass was fertilized with $\mathrm{N}$ approximately 3 wk before being harvested.

Wilting for $2.5 \mathrm{~h}$ increased the DM concentration of the mowed bermudagrass forage from 33.9 to $52.5 \%$. The DM concentration of wilted and baled control samples was lower than those of B500 and BPII haylages on d 0, but not lower than those of SI or SK haylages (Figure 1). The low standard error of the mean of the mown unwilted forage samples taken on d 0 (Table 1) shows that comparable forage samples were used for the experiment; however, differences in the extent to which the treated forages dried during the 2.5-h wilt caused differences in the DM concentrations of the wilted, baled d-0 samples in Figure 1. Consequently, the DM concentrations of the wilted, baled d-0 samples were used as covariates for the rest of the analyses to reduce or eliminate the effect of the differences in the extent of drying during wilting on the results.

The notable differences in DM concentrations between the wilted baled control haylage on $\mathrm{d} 0$ and

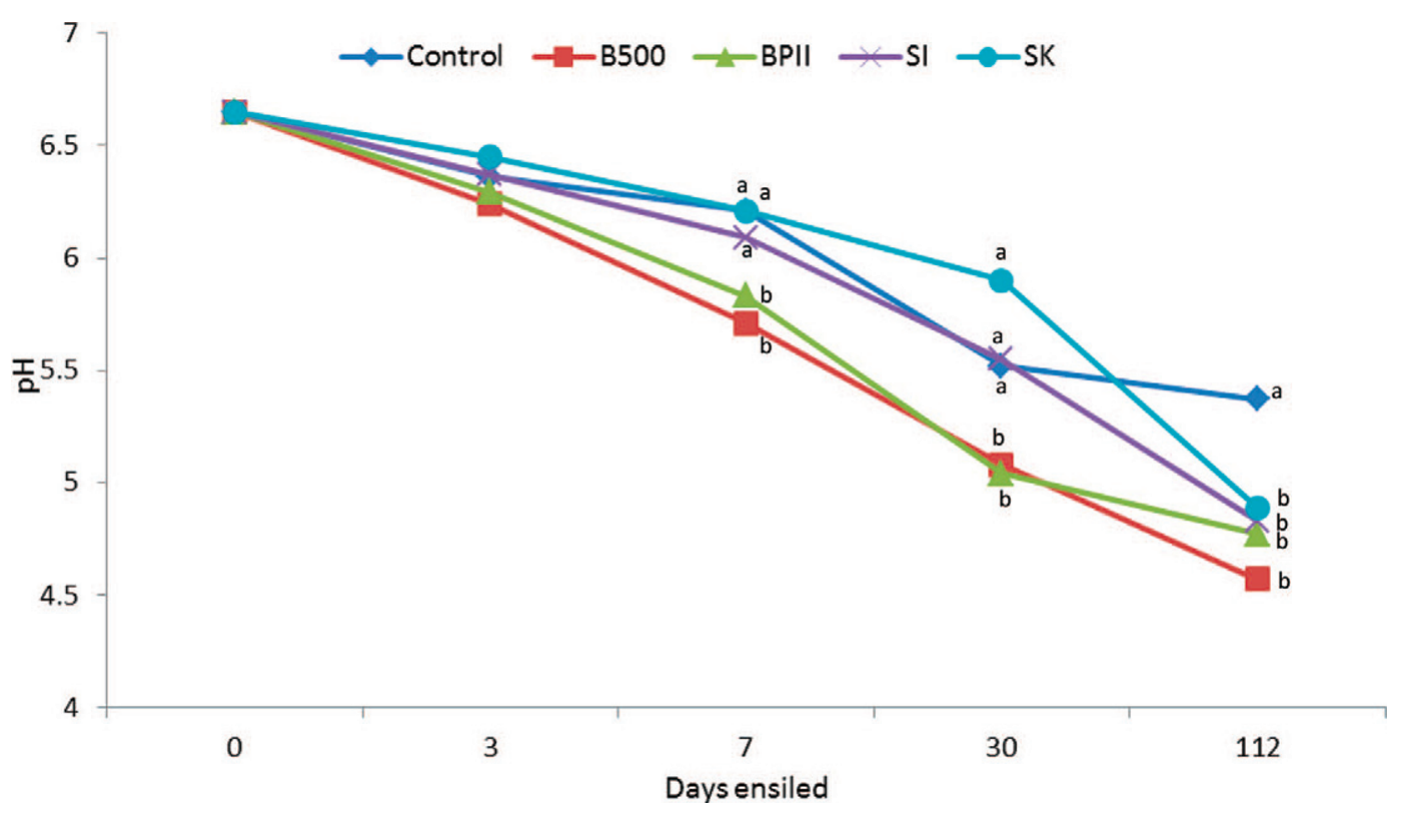

Figure 2. Effect of microbial inoculant treatment on the $\mathrm{pH}$ of bermudagrass haylages ensiled for different durations. Each of the effects of inoculant treatment, time and the interaction had a $P$-value of 0.001 . Means from the same day with different letters $(\mathrm{a}, \mathrm{b})$ differed at $P<0.05$. Standard errors of the means for the data from d 3, 7, 30, and 112 were 0.06, 0.04, 0.13, and 0.07, respectively. Control = no inoculant; B500 $=$ Pediococcus pentosaceus and Lactobacillus buchneri BPII $=$ P. pentosaceus and Propionibacteria freudenreichii; $\mathrm{SI}=$ Lactobacillus plantarum and $P$. pentosaceus; $\mathrm{SK}=L$. plantarum, Enterococcus faecium, and $P$. pentosaceus. Color version available online. 
the corresponding B500 and BPII haylages were not evident on $\mathrm{d} 112$. This was because of small increases in the dryness of the control haylage, but not the B500 and BPII haylages, over time. However, the underlying reason for the divergent trends is unclear.

The $\mathrm{pH}$ values of all $\mathrm{d}-3$ haylages were similar $(P=$ 0.29; Figure 2), but B500 and BPII had lower pH (5.77 vs. 6.17 and 5.06 vs. 5.66 , respectively; $P<0.001$ ) than other treatments after 7 and $30 \mathrm{~d}$ of ensiling. The more rapid $\mathrm{pH}$ decline in $\mathrm{B} 500$ and $\mathrm{BPII}$ haylages may be attributable to the $P$. pentosaceus they contained, which is tolerant of high-pH conditions and grows vigorously and dominates the epiphytic bacteria population during the early stages of ensiling (Kung et al., 2003).

By $112 \mathrm{~d}$ of ensiling, all treated haylages had a lower $\mathrm{pH}$ than the control haylage $(P<0.0001 ; 4.77$ vs. 5.37 ; Figure 2). This supports the hypothesis that the treatments would improve the fermentation of the haylages. Similarly, Adesogan et al. (2004) reported that inoculation with bacteria decreased the $\mathrm{pH}$ of bermudagrass silage after $60 \mathrm{~d}$ of ensiling in mini-silos (3.50 vs. 3.98). However, the difference in $\mathrm{pH}$ between inoculated and control haylages in the latter study and ours differed considerably. This reflects differences between the ideal ensiling conditions in the mini-silos used by Adesogan et al. (2004) and those in the bales used in the current study and commercial practice.

Haylages treated with SK had greater sugar concentration than other treatments (Table 2). This is partly attributable to haylage hydrolysis by the enzymes in SK and to choosing lactic acid bacteria strains for SK that minimize hexose sugar fermentation during ensiling such that more sugars are available for ruminal fermentation (G. A. Ayangbile, Agri-King Inc. Fulton, IL, personal communication).

Haylages treated with B500, BPII, and SK had lower ammonia concentration than SI haylages (Table 3; 5.3 vs. $7.9 \%$ of total N). Those treated with BPII and SK also had lower ammonia concentrations than the control, indicating that these treatments reduced deamination and perhaps proteolysis. Vendramini et al. (2012) reported that treating bermudagrass silage with microbial inoculants did not affect ammonia concentration. Haylages treated with SI tended $(P=0.06)$ to have lower $\mathrm{CP}$ concentration and had numerically greater soluble protein $(P=0.12)$ and greater $(P=0.001)$ ammonia concentration than the other haylages, suggesting that proteolysis and deamination were greater in the SI haylage. Gaseous losses of the ammonia and $\mathrm{N}_{2} \mathrm{O}$ resulting from the proteolysis and deamination may explain the low CP concentration of the SI haylage. Concentrations of acid-detergent insoluble protein were reduced by all inoculants except B500, suggesting 
Table 3. Microbial inoculant treatment effects on fermentation parameters of bermudagrass haylages after $112 \mathrm{~d}$ of ensiling

\begin{tabular}{|c|c|c|c|c|c|c|c|c|}
\hline Treatment $^{1}$ & $\begin{array}{c}\text { DM } \\
\text { Recovery, \% }\end{array}$ & $\mathrm{pH}$ & $\begin{array}{l}\text { Ammonia, } \\
\% \text { of TN }\end{array}$ & $\begin{array}{c}\text { Lactic acid, } \\
\% \text { DM }\end{array}$ & $\begin{array}{c}\text { Acetic acid, } \\
\text { \% DM }\end{array}$ & $\begin{array}{l}\text { Lactic acid: } \\
\text { acetic acid }\end{array}$ & $\begin{array}{l}\text { Ethanol, } \\
\text { \% DM }\end{array}$ & $\begin{array}{l}\text { Lactic acid:acetic } \\
\text { acid }+ \text { ethanol }\end{array}$ \\
\hline Control & 102 & $5.37^{\mathrm{a}}$ & $6.6^{\mathrm{b}}$ & 1.04 & 0.28 & $3.9^{\mathrm{c}}$ & $0.176^{\mathrm{b}}$ & $2.6^{\mathrm{c}}$ \\
\hline B500 & 98.8 & $4.57^{\mathrm{b}}$ & $5.7^{\mathrm{bc}}$ & 3.2 & 0.50 & $7.3^{\mathrm{a}}$ & $0.135^{\mathrm{b}}$ & $5.4^{\mathrm{a}}$ \\
\hline SI & 97.6 & $4.83^{\mathrm{b}}$ & $7.9^{\mathrm{a}}$ & 2.9 & 0.45 & $6.2^{\mathrm{abc}}$ & $0.318^{\mathrm{a}}$ & $3.6^{\mathrm{bc}}$ \\
\hline SK & 102 & $4.89^{\mathrm{b}}$ & $5.2^{\mathrm{c}}$ & 1.8 & 0.41 & $4.5^{\mathrm{bc}}$ & $0.174^{\mathrm{b}}$ & $3.1^{\mathrm{c}}$ \\
\hline SEM & 1.62 & 0.07 & 0.33 & 0.35 & 0.04 & 1.07 & 0.05 & 0.39 \\
\hline
\end{tabular}

${ }^{\mathrm{a}-\mathrm{c}}$ Means with different superscripts in the same column differed, $P<0.05$.

${ }^{1}$ Control $=$ no inoculant; $\mathrm{B} 500=$ Pediococcus pentosaceus and Lactobacillus buchneri $\mathrm{BPII}=$ P. pentosaceus and Propionibacteria freudenreichii; $\mathrm{SI}=$ Lactobacillus plantarum and $P$. pentosaceus; $\mathrm{SK}=$ L. plantarum, Enterococcus faecium, and $P$. pentosaceus.

that BPII, SI, and SK increased the availability of the $\mathrm{N}$ in the forage.

The B500, BPII, and SI inoculants tended to increase lactic acid concentration compared with SK and control (Table $3 ; P=0.08 ; 2.9$ vs. $1.42 \% \mathrm{DM}$ ), and all treatments tended to have greater acetic acid concentrations compared with the control $(P=0.05 ; 0.44$ vs. $0.28 \%$ DM). In contrast, Vendramini et al. (2012) reported that lactic acid concentrations were reduced by treatment of bermudagrass silage with B500, though acetic acid concentrations were unaffected. Differences between the latter results and those in our study probably reflect the different storage methods. No other VFA were detected in the haylages. Ethanol concentrations were greater in SI haylages than others. The lactic-toacetic acid ratio and lactic-to-acetic acid plus ethanol ratio were greater in B500 and BPII than control haylages (6.7 vs. 4.2 and 5.2 vs. 2.6, respectively), which indicates that the fermentation processes in the former haylages were more efficient.

No difference was observed among haylage yeast counts, but treated haylages tended to have lower mold counts than control haylages $(P=0.06 ; 4.47$ vs. 2.73 $\mathrm{cfu} / \mathrm{g}$; Table 4). This may have been because inoculation tended to increase haylage concentrations of acetic acid, which is a strong antifungal acid (Moon, 1983). The SK haylage also had lower clostridia counts than the control haylage $(P=0.03 ; 1.19$ vs. $2.13 \mathrm{cfu} / \mathrm{g})$ for unknown reasons.

As reported by Vendramini et al. (2012) for bermudagrass silage, aerobic stability was improved by all inoculant treatments. However, the magnitude of the improvement was greatest for B500 and least for SK. Treatments B500, BPII, SI, and SK improved $(P<$ 0.001 ) aerobic stability by $236,197,188$, and $95 \%$, respectively, compared with the control (276 vs. $99 \mathrm{~h}$ ). Therefore, as hypothesized, application of the inoculants increased the aerobic stability of the haylages. It is also interesting to note that inoculants containing obligate heterolactic bacteria as well as homolactic or facultative heterolactic bacteria had numerically greater aerobic stability improvements than those containing the latter solely. That the former also resulted in quicker acidification of the forage is probably attributable to the vigorous growth of $P$. pentosaceus early in the fermentation relative to those of other bacteria (Kung et al., 2003). The slower acidification rate in haylages treated with SI and SK, which also contained P. pentosaceus, may be due to competition with $L$. plantarum and E. faecium and to strain differences.

Table 4. Microbial inoculant treatment effects on microbial counts (log cfu/g), and aerobic stability (h) of bermudagrass haylages after $112 \mathrm{~d}$ of ensiling

\begin{tabular}{lccccc}
\hline Treatment $^{1}$ & Yeast & Mold & Clostridia & Coliform & $\begin{array}{c}\text { Aerobic } \\
\text { stability }\end{array}$ \\
\hline Control & 1.03 & 4.47 & $2.13^{\mathrm{a}}$ & 1.82 & $99.0^{\mathrm{c}}$ \\
B500 & 0.98 & 2.45 & $2.09^{\mathrm{ab}}$ & 0.88 & $333^{\mathrm{a}}$ \\
BPII & 1.22 & 2.89 & $1.97^{\mathrm{ab}}$ & 1.30 & $294^{\mathrm{a}}$ \\
SI & 1.01 & 1.97 & $1.75^{\mathrm{ab}}$ & 1.80 & $285^{\mathrm{a}}$ \\
SK & 1.00 & 3.62 & $1.19^{\mathrm{b}}$ & 1.34 & $193^{\mathrm{b}}$ \\
SEM & 0.12 & 0.58 & 0.23 & 0.49 & 22.4 \\
$P$-value & 0.55 & 0.06 & 0.03 & 0.79 & 0.001 \\
\hline
\end{tabular}

${ }^{\mathrm{a}-\mathrm{c}}$ Means with different superscripts in the same column differed, $P<0.05$.

${ }^{1}$ Control $=$ no inoculant; $\mathrm{B} 500=$ Pediococcus pentosaceus and Lactobacillus buchneri; $\mathrm{BPII}=$ P. pentosaceus and Propionibacteria freudenreichii; SI = Lactobacillus plantarum and P. pentosaceus; SK $=$ L. plantarum, Enterococcus faecium, and P. pentosaceus. 


\section{CONCLUSIONS}

Each of the microbial inoculants improved the fermentation of bermudagrass haylage, as evidenced by the lower haylage $\mathrm{pH}$ after $112 \mathrm{~d}$ of ensiling (4.77 vs. 5.37). Nevertheless, the $\mathrm{pH}$ of B500 and BPII haylages decreased more rapidly than those of other haylages. All inoculants except SK increased the lactic acid concentration and lactic-to-acetic acid ratio of haylages, indicating they made the fermentations more homolactic. All inoculants, except SI, reduced haylage ammonia-N concentrations, indicating reduced protein deamination. Clostridia counts were reduced by SK, but all inoculants tended to decrease mold counts. Inoculants B500, BPII, SI, and SK increased aerobic stability by $236,197,188$, and $95 \%$, respectively. This study indicates that microbial inoculants containing only homolactic bacteria or those containing homolactic and heterolactic bacteria can be used to improve the fermentation and aerobic stability of bermudagrass haylage. These results relate to the inoculants and the forage examined in this study. It is likely that inoculant application will have similar beneficial effects on the preservation and quality of other bermudagrasses, or tropical and subtropical forages, but this needs to be verified in research trials.

\section{ACKNOWLEDGMENTS}

We gratefully acknowledge funding of this study by Southeast Milk Dairy Check-Off Incorporated and Lallemand Animal Nutrition Inc. (Milwaukee, WI). We are also grateful to Agri-King Inc. (Fulton, IL) for the laboratory analysis.

\section{REFERENCES}

Adesogan, A. T., N. Krueger, M. B. Salawu, D. B. Dean, and C. R. Staples. 2004. The influence of treatment with dual purpose microbial inoculants or soluble carbohydrates on the fermentation and aerobic stability of bermudagrass. J. Dairy Sci. 87:3407-3416.

Adesogan, A. T., M. B. Salawu, A. B. Ross, D. R. Davies, and A. E. Brooks. 2003. Effect of Lactobacillus buchneri, L. fermentum or Leuconostoc mesenteroides inoculants or a chemical additive on the fermentation, aerobic stability and nutritive value of crimped wheat grains. J. Dairy Sci. 86:1789-1796.

AOAC International. 1999. Official Methods of Analysis. 16th ed. AOAC International, Gaithersburg, MD.

Arriola, K. G., S. C. Kim, and A. T. Adesogan. 2011a. Effect of applying inoculants with heterolactic or homolactic and heterolactic bacteria on the fermentation and quality of corn silage. J. Dairy Sci. 94:1511-1516.

Arriola, K. G., S. C. Kim, C. R. Staples, and A. T. Adesogan. 2011 b. Effect of applying microbial inoculants containing different types of bacteria to corn silage on the performance of dairy cattle. J. Dairy Sci. 94:3973-3979.

Ayangbile, O. A., J. C. Meier, and M. K. Vogel, J. Robertson, A. R. McElRoy, and A. R. Komarek. 1995. Cryogenically protected and fresh rumen inoculum for digestibility study. Abstract 1 in Proc. 23rd Biennial Conf. Rumen Function, Vol. 23. Chicago, IL. University of Illinois, Urbana.

Cancalon, P. F. 1993. Rapid monitoring of fruit juice adulteration by capillary electrophoresis. Liquid Chromatography Gas Chromatography 11:748-751.

Dawson, T. E., S. R. Rust, and M. T. Yokoyama. 1998. Improved fermentation and aerobic stability of ensiled high moisture corn with the use of Propionibacterium acidipropionici. J. Dairy Sci. 81:1015-1021.

Dean, D. B., A. T. Adesogan, N. Krueger, and R. C. Littell. 2005. Effect of fibrolytic enzymes on the fermentation characteristics, aerobic stability, and digestibility of bermudagrass silage. J. Dairy Sci. 88:994-1003.

Driehuis, F., S. J. W. H. Oude Elferink, and P. G. Van Wikselaar. 2001. Fermentation characteristics and aerobic stability of grass silage inoculated with Lactobacillus buchneri, with or without homofermentative lactic acid bacteria. Grass Forage Sci. 56:330-343.

Filya, I., E. Sucu, and A. Karabulut. 2004. The effect of Propionibacterium acidipropionici, with or without Lactobacillus plantarum, on the fermentation and aerobic stability of wheat, sorghum and maize silages. J. Appl. Microbiol. 97:818-826.

Filya, I., E. Sucu, and A. Karabulut. 2006. The effect of Propionibacterium acidipropionici and Lactobacillus plantarum, applied at ensiling, on the fermentation and aerobic stability of low dry matter corn and sorghum silages. J. Ind. Microbiol. Biotechnol. 33:353-358.

Higginbotham, G. E., S. C. Mueller, K. K. Bolsen, and E. J. DePeters. 1998. Effects of inoculants containing propionic acid bacteria on fermentation and aerobic stability of corn silage. J. Dairy Sci. 81:2185-2192.

Hill, G. M., R. N. Gates, and G. W. Burton. 1993. Forage quality and grazing steer performance from Tifton 85 and Tifton 78 bermudagrass pastures. J. Anim. Sci. 71:3219-3225.

Huisden, C. M., A. T. Adesogan, S. C. Kim, and T. Ososanya. 2009. Effect of applying molasses or inoculants containing homofermentative or heterofermentative bacteria at two rates on the fermentation and aerobic stability of corn silage. J. Dairy Sci. 92:690-697.

Kleinschmit, D. H., R. J. Schmidt, and L. Kung Jr.. 2005. The effects of various antifungal additives on the fermentation and aerobic stability of corn silage. J. Dairy Sci. 88:2130-2139.

Krishnamoorthy, U., T. V. Muscato, C. J. Sniffen, and P. J. Van Soest. 1982. Nitrogen fractions in selected feedstuffs. J. Dairy Sci. $65: 217-225$.

Krueger, N. A., A. T. Adesogan, C. R. Staples, W. K. Krueger, S. C. Kim, R. C. Littel, and L. E. Sollenberger. 2008. Effect of method of applying fibrolytic enzymes or ammonia to bermudagrass hay on feed intake, digestion and growth of beef steers. J. Anim. Sci. 86:882-889.

Kung, L., Jr., M. R. Stokes, and C. J. Lin. 2003. Silage additives. Pages 305-360 in Silage Science and Technology (Agronomy Series No. 42). Buxton, D. R., Muck, R.E., and J. H. Harrison, ed. American Society of Agronomy. Madison, WI.

Kunkle, W. E., D. B. Bates, C. G. Chambliss, and R. P. Cromwell. 1988. Alternative forage storage-bale silage. Pages 31-41 in Proc. Dairy Herd Manag. Conf., Univ. Georgia, Athens.

McDonald, P., and A. R. Henderson. 1962. Buffering capacity of herbage samples as a factor in ensilage. J. Sci. Food Agric. 13:395-400

Moon, N. J. 1983. Inhibition of the growth of acid tolerant yeasts by acetate, lactate and propionate and their synergistic mixtures. J. Appl. Bacteriol. 55:454-460.

Peters, J., S. Combs, B. Hoskins, J. Jarman, J. Kovar, M. Watson, A. Wolf, and N. Wolf. 2003. Recommended methods of manure analysis. Cooperative Extension Publishing, Madison WI.

Ranjit, N. K., and L. Kung Jr. 2000. The effect of Lactobacillus buchneri, Lactobacillus plantarum, or a chemical preservative on the fermentation and aerobic stability of corn silage. J. Dairy Sci. $83: 526-535$

Vendramini, J. M. B., A. T. Adesogan, M. L. A. Silveira, L. E. Sollenberger, O. C. M. Queiroz, and W. F. Anderson. 2010. Nutritive 
value and fermentation parameters of warm-season grass silage. Prof. Anim. Sci. 26:193-200.

Vendramini, J. M. B., A. T. Adesogan, L. E. Sollenberger, A. D. Aguiar, A. Valente, and P. Salvo. 2012. Effects of DM concentration and inoculants on Jiggs and Tifton 85 bermudagrass silage. J. Anim. Sci. 90(Suppl. 3.):534.

Weinberg, Z. G., G. Ashbell, K. K. Bolsen, G. Pahlow, Y. Hen, and A. Azrieli. 1995. The effect of a propionic acid microbial inoculants applied at ensiling, with or without lactic acid bacteria, on the aerobic stability of pearl millet and maize silages. J. Appl. Bacteriol. 78:430-436.

West, J. W., P. Mandebvu, G. M. Hill, and R. N. Gates. 1998. Intake, milk yield, and digestion by dairy cows fed diets with increasing fiber content from bermudagrass hay or silage. J. Dairy Sci. 81:1599-1607. 